\begin{tabular}{|c|c|c|c|}
\hline \multirow[t]{2}{*}{ CPF\#28 } & \multirow{2}{*}{ ENGINEERING CHANGE NOTICE } & \multirow[b]{2}{*}{ Page 1 of 2} & 1. ECN 657944 \\
\hline & & & $\begin{array}{l}\text { Proj. } \\
\text { ECN }\end{array}$ \\
\hline
\end{tabular}

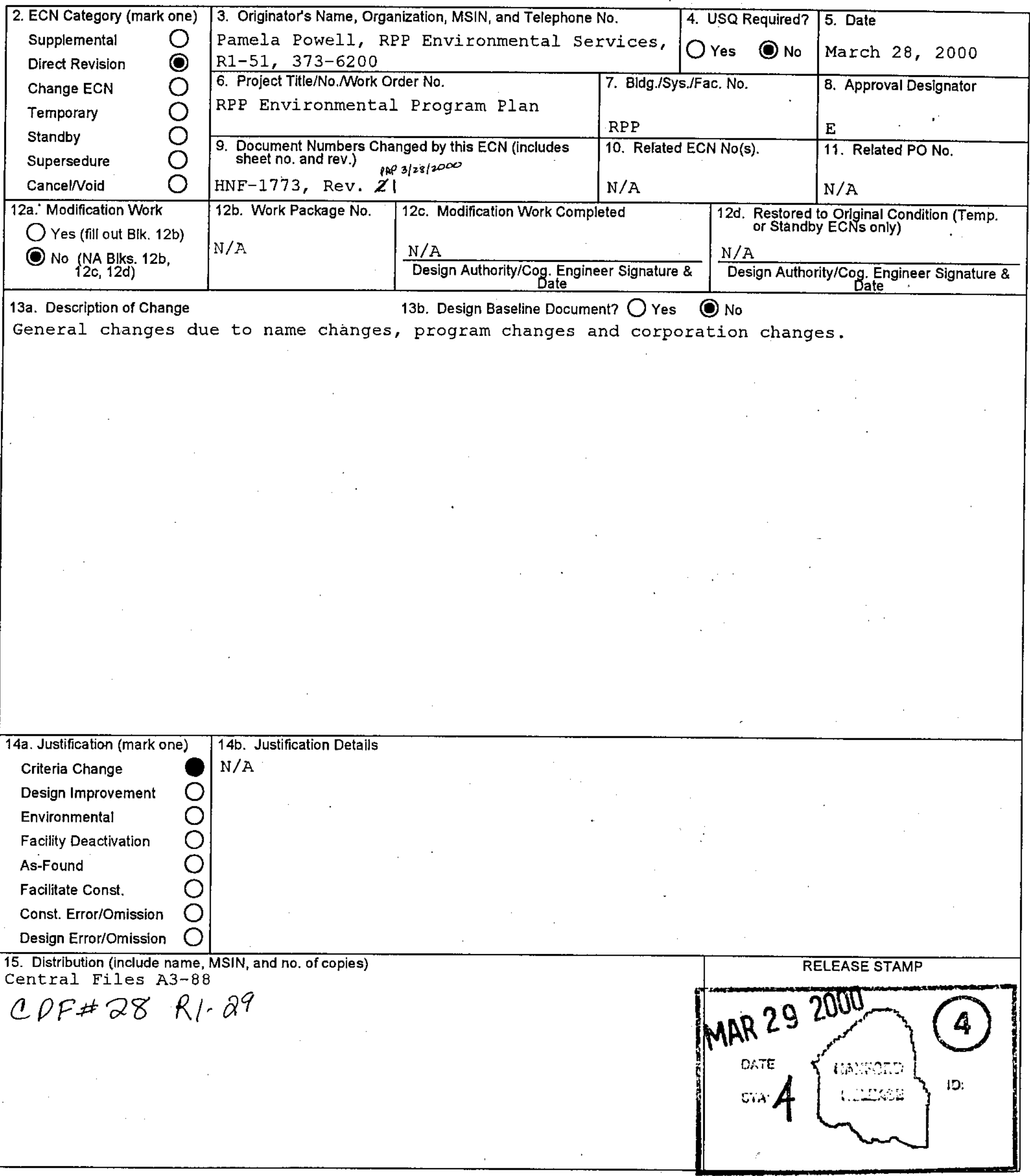


Page 2 of 2

16. Design Verification Required

OYes

O No
17. Cost Impact

ENGINEERING

Additional $\bigcirc \$$

Savings $\bigcirc \$$
CONSTRUCTION

Additional $\bigcirc \$$

Savings $\mathrm{O} \$$
1. ECN (Use no. from pg. 1)

657944

18. Schedule Impact (days)

Improvement

Delay

19. Change Impact Review: Indicate the related documents (other than the engineering documents identified on Side 1) that will be affected by the change described in Block 13. Enter the affected document number in Block 20.

SDD/DD

Functional Design Criteria

Operating Specification

Criticality Specification

Conceptual Design Report

Equipment Spec.

Const. Spec.

Procurement Spec.

Vendor Information

OM Manual

FSAR/SAR

Safety Equipment List

Radiation Work Permit

Environmental Impact Statement

Environmental Report

Environmental Permit

$\square$
$\square$
$\square$
$\square$
$\square$
$\square$
$\square$
$\square$
$\square$
$\square$
$\square$
$\square$
$\square$
$\square$
$\square$

Seismic/Stress Analysis
Stress/Design Report
Interface Control Drawing
Calibration Procedure
Installation Procedure
Maintenance Procedure
Engineering Procedure
Operating Instruction
Operating Procedure
Operational Safety Requirement
IEFD Drawing
Cell Arrangement Drawing
Essential Material Specification
Fac. Proc. Samp. Schedule
Inspection Plan
Inventory Adjustment Request

Tank Calibration Manual Health Physics Procedure Spares Multiple Unit Listing Test Procedures/Specification Component Index ASME Coded Item Human Factor Consideration Computer Software

Electric Circuit Schedule ICRS Procedure Process Control Manual/Plan Process Flow Chart Purchase Requisition Tickler File

20. Other Affected Documents: (NOTE: Documents listed below will not be revised by this ECN.) Signatures below indicate that the signing organization has been notified of other affected documents listed below.

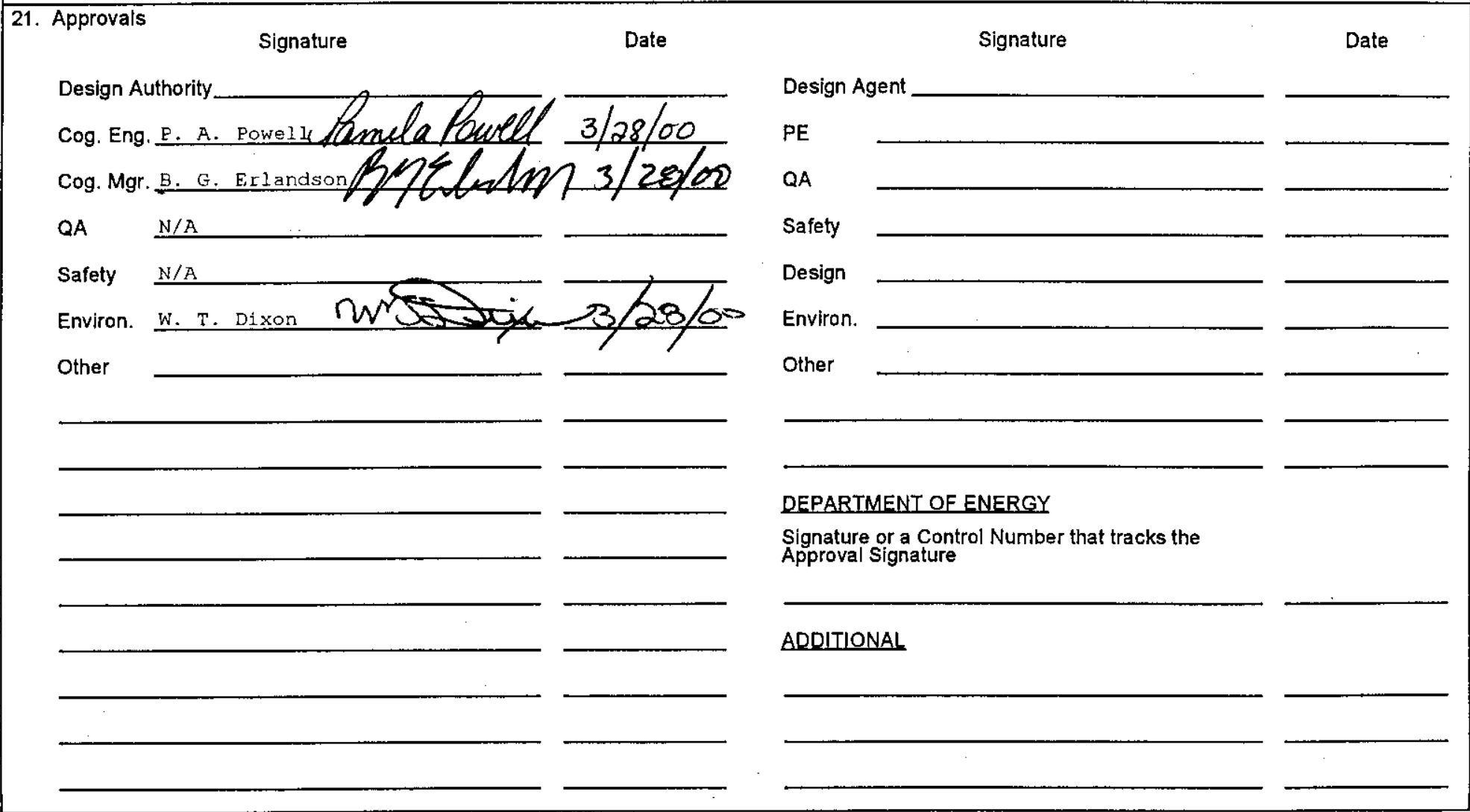


HNF-1773

Revision 2

\section{River Protection Project Environmental Program Plan}

Prepared for the U.S. Department of Energy

Assistant Secretary for Environmental Management

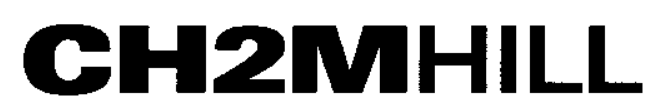

Hanford Group, Inc.

Richland, Washington

Contractor for the U.S. Department of Energy

Office of River Protection under Contract DE-AC06-99RL14047

Approved for Public Release; Further Dissemination Unlimited 


\section{LEGAL DISCLAIMER}

This report was prepared as an account of work sponsored by an agency of the United States Government. Neither the United States Government nor any agency thereof, nor any of their employees, nor any of their contractors, subcontractors or their employees, makes any warranty, express or implied, or assumes any legal liability or responsibility for the accuracy, completeness, or any third party's use or the results of such use of any information, apparatus, product, or process disclosed, or represents that its use would not infringe privately owned rights. Reference herein to any specific commercial product, process, or service by trade name, trademark, manufacturer, or otherwise, does not necessarily constitute or imply its endorsement, recommendation, or favoring by the United States Government or any agency thereof or its contractors or subcontractors. The views and opinions of authors expressed herein do not necessarily state or reflect those of the United States Government or any agency thereof.

This report has been reproduced from the best available copy.

Available in paper copy and microfiche.

Available electronically at http://www.doe.gov/bridge. Available for a processing fee to the U.S. Department of Energy and its contractors, in paper, from:

U.S. Department of Energy

Office of Scientific and Technical Information P.O. Box 62

Oak Ridge, TN 37831-0062

phone: 865-576-8401

fax: 865-576-5728

email: reports@adonis.osti.gov(423) 576-8401

Available for sale to the public, in paper, from:

U.S. Department of Commerce

National Technical Information Service

5285 Port Royal Road

Springfield, VA 22161

Phone: 800-553-6847

fax: 703-605-6900

email: orders@ntis.fedworld.gov

online ordering:

http://www.ntis.gov/ordering.htm 


\title{
River Protection Project Environmental Program Plan
}

\author{
P.A. Powell \\ CH2M HILL Hanford Group, Inc., Richland, WA 99352 \\ Richland, WA 99352 \\ U.S. Department of Energy Contract DE-AC06-96Rt 13200 \\ 9921.14047 \\ EDT/ECN: 657944 \\ Org Code: 7B200 \\ UC: 2030 \\ Charge Code: \\ B\&R Code: \\ Total Pages: $\$ 648$
}

Key Words: Environmental, RPP Program Plan

Abstract: This Environmental Program Plan has been developed in support of the Integrated Environmental, Safety, and Health Mangement system and consistent witht he goals of DOE/RL-96-50, Hanford strategic Plan (RL 1996a).

TRADEMARK DISCLAIMER. Reference herein to any specific commercial product, process, or service by trade name, trademark, manufacturer, or otherwise, does not necessarily constitute or imply its endorsement, recommendation, or favoring by the United States Government or any agency thereof or its contractors or subcontractors.

Printed in the United States of America. To obtain copies of this document, contact: Document Control Services, P.O. Box 950, Mailstop H6-08, Richland WA 99352, Phone (509) 372-2420; Fax (509) 376-4989.
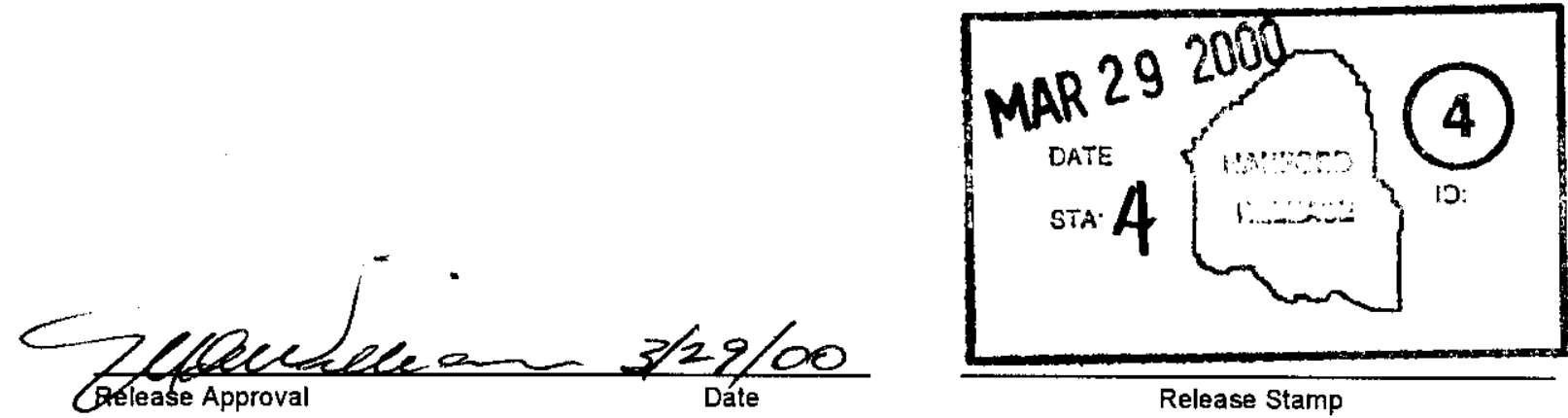

Release Stamp 
RECORD OF REVISION

(2) Title

River Protection Program Environmental Program Plan

Change Control Record

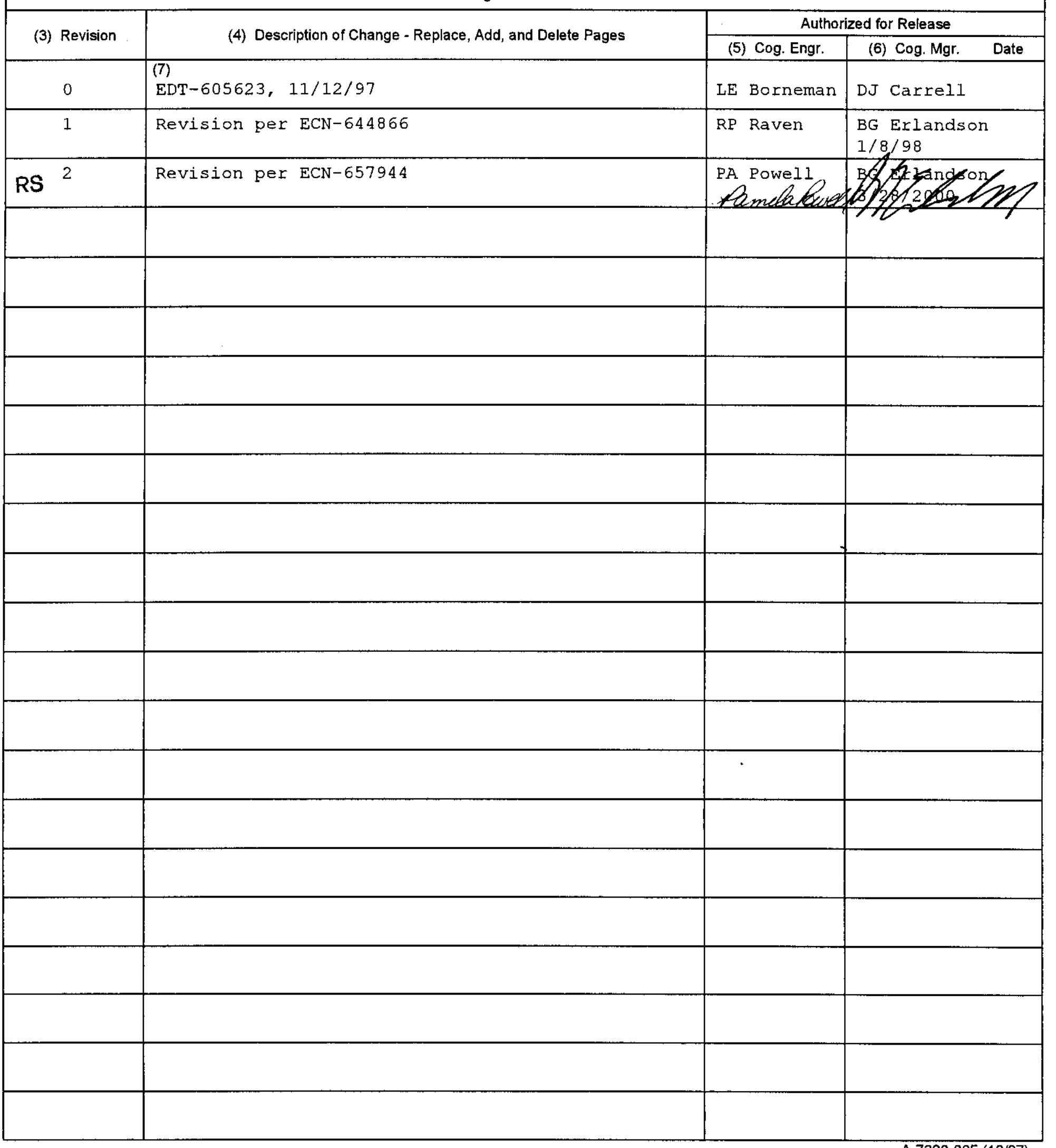


HNF-1773

Revision 2

\section{River Protection Project Environmental Program Plan}

Prepared by:

P. A. Powell

CH2M HILL Hanford Group, Incorporated

Date Published

March 2000

Prepared for the U.S. Department of Energy

Assistant Secretary for Environmental Management

\section{CH2MHILL}

Hanford Group, Inc.

P. O. Box 1500

Richland, Washington

Contractor for the U.S. Department of Energy

Office of River Protection under Contract DE-AC06-99RL14047

Approved for Public Release; Further Dissemination Unlimited 
HNF-1773 Rev. 2

This page intentionally left blank. 

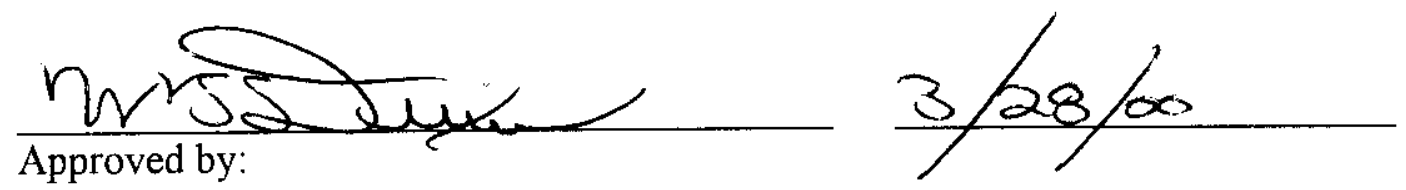

W. T. Dixon, Manager

Date

RPP Environmental Services

CH2M HILL Hanford Group, Inc. 
HNF-1773 Rev. 2

This page intentionally left blank. 


\section{CONTENTS}

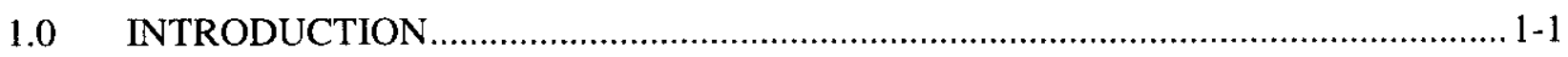

2.0 ESTABLISH ENVIRONMENTAL POLICY ……..................................................... $2-1$

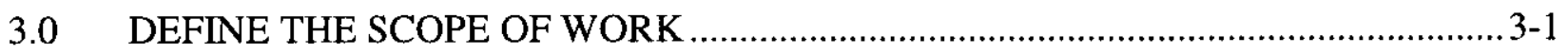

3.1 RIVER PROTECTION PROJECT INTEGRATED PLANNING

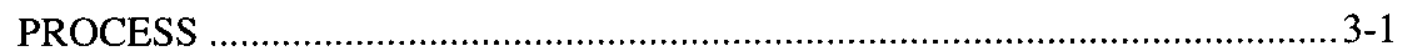

3.2 RIVER PROTECTION PROJECT ENVIRONMENTAL WORK SCOPE DESCRIPTIONS.....................................................................................

4.0 IDENTIFY HAZARDS, ENVIRONMENTAL IMPACTS, AND REQUIREMENTS .......................................................................................... 4-1

4.1 MECHANISMS TO IDENTIFY ENVIRONMENTAL IMPACTS ....................4-1

4.1.1 National Environmental Policy Act of 1969 Review and Related Laws ................................................................................................ 4-1

4.1.2 Environmental Monitoring ……............................................................4-2

4.1.3 Spill and Release Reporting ………….............................................4-5

4.1.4 Chemical Management.................................................................. 4-5

4.1.5 Pollution Prevention and Waste Minimization Program...........................4-6

4.1.6 Waste-Generation Tracking and Reporting............................................4-6

4.2 IDENTIFICATION OF ENVIRONMENTAL REQUIREMENTS .....................4-7

4.2.1 Existing Permits and Regulatory Agreements ........................................4-7

4.2.2 Environmental Requirements Management ............................................ 4-10

5.0 ANALYZE HAZARDS AND ENVIRONMENTAL IMPACTS AND

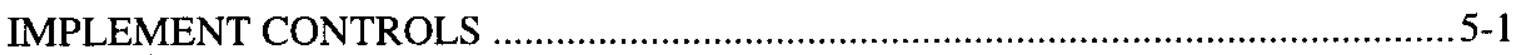

5.1 WORK-PLANNING PROJECT LEVEL ………........................................... 5-1

5.2 WORK-PLANNING ACTIVITY LEVEL ………….....................................5-1

5.3 RIVER PROTECTION PROJECT PROJECTS AND ACTIVITIES: INTEGRATED PERMITTING SCHEDULE ................................................5-2

5.3.1 Resource Conservation and Recovery Act of 1976 Permit .......................5-2

5.3.2 Notice of Construction Applications ..........................................................5-3

5.4 IMPLEMENTATION OF PERMIT CONDITIONS .......................................... 5-3

6.0 PERFORM WORK WITHIN CONTROLS ……...................................................... 6-1

6.1 EMPLOYEE TRAINING AND QUALIFICATION PROGRAM......................6-1

6.2 CONFIRMING READINESS TO PERFORM THE WORK ……........................ 6-1

6.3 PERFORMING WORK ……………........................................................ 6-2

7.0 PROVIDE FEEDBACK AND CONTINUOUS IMPROVEMENT ……….................... 7-1

$7.1 \quad$ PERFORMANCE MEASURES …….......................................................... 7-1

7.1.1 Goal: Complete Radioactive and Nonradioactive Notices of Construction on Schedule. 
7.1.2 Goal: Maintain an Efficient Environmental Oversight Program by Responding to Program Indicators.

7.1.3 Goal: Reduce the Number of Regulatory Agency Findings. .................. 7-1

7.1.4 Goal: Meet All Tri-Party Agreement Milestone Commitments. ............. 7-1

7.2 ENVIRONMENTAL SURVEILLANCE PROGRAM ................................ $7-1$

7.2.1 Management Assessments........................................................... 7-2

7.2.2 Surveillance/Compliance Inspections ............................................ 7-2

7.2.3 Functional Assessments ............................................................ 7-2

7.2.4 Subcontractor Management Assessments ....................................... 7-2

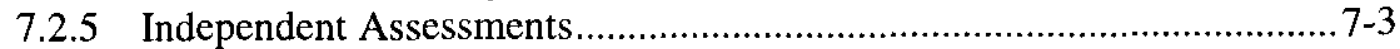

7.2.6 External Audits.............................................................................. 7-3

7.3 COMMITMENT TRACKING AND OCCURRENCE TRENDING .............. 7-3

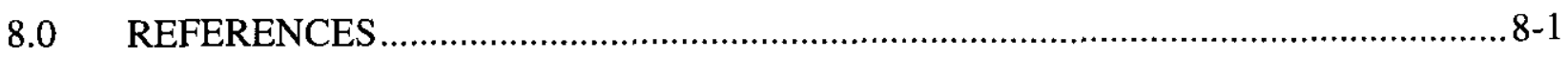

\begin{abstract}
APPENDIX
A Information Needed to Support Site Wide Reporting .............................................. A-i
\end{abstract}

\title{
TABLES
}

Table 1. River Protection Project Emission Stacks. 
HNF-1773 Rev. 2

\section{TERMS}

ALARACT
AOP
CFR
DCRT
DOE
DST
Ecology
EPA
FEMP
ISMS
NEPA
NESHAP
NOC
PNNL
RCRA
RL
RMCS
RPP
S/RID
SST
Tri-Party Agreement
TSD
TWRS
WAC
WDOH
WMH

as-low-as-reasonably-achievable control technology air operating permit Code of Federal Regulations double-contained receiver tank U.S. Department of Energy double-shell tank Washington State Department of Ecology U.S. Environmental Protection Agency Facility Effluent Monitoring Plan Integrated Environment, Safety, and Health Management System National Environmental Policy Act of 1969

National Emission Standards for Hazardous Air Pollutants notice of construction Pacific Northwest National Laboratory Resource Conservation and Recovery Act of 1976 U.S. Department of Energy, Richland Operations Office rotary-mode core sampling River Protection Project standards and requirements identification document single-shell tank Hanford Federal Facility Agreement and Consent Order treatment, storage, and disposal Tank Waste Remediation System (prior name of RPP) Washington Administrative Code Washington State Department of Health Waste Management Federal Services of Hanford, Inc. 
HNF-1773 Rev. 2

This page intentionally left blank. 
HNF-1773 Rev. 2

\section{RIVER PROTECTION PROJECT ENVIRONMENTAL PROGRAM PLAN}

\subsection{INTRODUCTION}

This Environmental Program Plan was developed in support of the Integrated Environment, Safety, and Health Management System Plan (ISMS) (RPP-MP-003), which establishes a single, defined environmental, safety, and health management system that integrates requirements into the work planning and execution processes to protect workers, the public, and the environment. The ISMS also provides mechanisms for increasing worker involvement in work planning, including hazard and environmental impact identification, analysis, and control; work execution; and feedback/improvement processes. The ISMS plan consists of six core functions. Each section of this plan describes the activities of the River Protection Project (RPP) (formerly known as the Tank Waste Remediation System) Environmental organization according to the following core functions:

- Establish Environmental Policy

- Define the Scope of Work

- Identify Hazards, Environmental Impacts, and Requirements

- Analyze Hazards and Environmental Impacts and Implement Controls

- Perform Work within Controls

- Provide Feedback and Continuous Improvement. 
HNF-1773 Rev. 2

This page intentionally left blank. 
HNF-1773 Rev. 2

\subsection{ESTABLISH ENVIRONMENTAL POLICY}

It is the policy of the RPP that the project and our employees will be stewards of the environment, reflecting the Office of River Protection policies. Protection of the environment, including protection of natural, archaeological, cultural, and historical resources and the public health, is a primary consideration in our activities. The RPP is committed to achieving environmental excellence by systematically integrating environmental, safety, and health principles with other Hanford Prime Contractors.

To foster environmental stewardship, the RPP will work together with our customer and subcontractors, regulators, tribal nations, stakeholders, and the public, to perform the following:

- Consider the impacts of our activities on the environment

- Comply with applicable laws, regulations, permits, and directives

- Develop innovative programs to safeguard the environment and maintain a cost-effective and flexible business approach to completing the clean-up mission .

- Integrate pollution prevention, resource conservation, waste minimization, and environmental-impact considerations into our planning, decision-making, designs, training, and daily work activities

- Identify and mitigate existing adverse environmental conditions and anticipate, eliminate, or mitigate future environmental impacts before they pose a threat to our environment, using a risk-based graded approach

- Promptly report and seek to correct environmental incidents and deficiencies

- Continually assess our performance and implement opportunities to achieve a common goal of environmental excellence

- Communicate our goals and progress to our employees.

The RPP management team and employees are responsible for conducting work consistent with this policy. The RPP Environmental organization reports to the RPP Director of Environment, Safety, and Health. 
HNF-1773 Rev. 2

This page intentionally left blank. 


\subsection{DEFINE THE SCOPE OF WORK}

Defining the scope of work is critical in budget formulation and resource allocation. It also is necessary to set the stage for identification and analyses of potential work hazards and environmental impacts (ISMS core functions 3 and 4).

\subsection{RIVER PROTECTION PROJECT INTEGRATED PLANNING PROCESS}

The integrated planning process defines the technical scope, schedule, and cost data necessary to establish the integrated baselines that are summarized in the multiyear work plans (RPP-MD-023, Multi-Year Work Plan [MYWP] Scheduling). This process provides the information necessary to adequately define the work scope, which is the basis for the project estimates and schedules. The process is performed at multiple levels of work definition and includes all functional RPP organizations.

The integrated planning process requires a project management team composed of qualified technical representatives who ensure that the technical, safety, environmental, regulatory, operations, radiological, and business management aspects of the project are addressed. The project management team meets in planned sessions to prepare level 1 logic diagrams for new identified work scope or to revise level 1 logic diagrams for proposed work scope changes. The logic diagrams address all aspects of the project including preparation work; operational facility/equipment disposition, deactivation, and demolition phases; and safety, environmental, and regulatory requirements. Level 1 logic diagrams are further broken down into level 2 diagrams. Level 2 is the level of work definition where resource requirements are quantified.

The work scope definition is included in the project/mission logic diagrams, project plans, risk analysis reports, and a technical-basis-review planning package. A technical-basis-review planning package documents the technical scope, schedule, and cost-estimate data at the activity and subactivity levels. When technical and schedule aspects of the work definition are validated, detailed schedules are developed and resources are allocated to the activities. The final scope, schedule, and supporting cost estimates serve as the basis for developing performance agreements and the multiyear work plans (RPP-MD-023).

\subsection{RIVER PROTECTION PROJECT ENVIRONMENTAL WORK SCOPE DESCRIPTIONS}

RPP Environmental support is identified in various technical-basis-review planning packages. The following work scope descriptions for RPP Environmental came out of the RPP integrated planning process:

- Respond to environmental issues (notices of correction and/or violations, regulatory agency inquiries)

- Manage minor effluent sources/permitting 
HNF-1773 Rev. 2

- Develop an operations environmental requirements program plan

- Establish baseline regulatory files and maintain regulatory files for compliance

- Implement/maintain the RPP portions of the Sitewide air operating permit

- Develop and issue notices of construction

- Review and revise data quality objectives

- Maintain the radionuclide air emission program

- Prepare environmental reports

- Provide environmental subcontractor oversight

- Perform hazardous material coordination

- Support agency inspections/investigations (Washington State Department of Health [WDOH], Washington State Department of Ecology [Ecology], U.S. Environmental Protection Agency [EPA])

- Update the double-shell tank (DST) Resource Conservation and Recovery Act of 1976 (RCRA) Part B permit application

- Implement the RPP Chemical Management System

- Maintain the RPP standards and requirements identification document (S/RID), Sections 13, 16, and 20 (Biebesheimer 1996); conduct S/RID phase I and II assessments; manage deficiencies.

- Perform environmental assessments

- Implement/maintain an environmental inspection program

- Establish/maintain regulatory compliance in tank farms and ancillary facilities

- Support Waste Retrieval and related projects

- Support the Privatization Contractor. 


\subsection{IDENTIFY HAZARDS, ENVIRONMENTAL IMPACTS, AND REQUIREMENTS}

Identification of potential hazards and environmental impacts is a continual process because of the variety of work activities performed within the RPP and related projects. The RPP Environmental organization identifies the environmental impacts of RPP activities through several mechanisms such as National Environmental Policy Act of 1969 (NEPA) documentation, environmental monitoring, spill reporting, chemical-use tracking and reporting, pollutionprevention opportunity assessments, and waste-generation tracking and reporting. Each mechanism is discussed separately in the following sections.

Environmental requirements are identified and managed in existing RPP permits and regulatory agreements as well as through the RPP S/RID (Biebesheimer 1996).

\subsection{MECHANISMS TO IDENTIFY ENVIRONMENTAL IMPACTS}

\subsubsection{National Environmental Policy Act of 1969 Review and Related Laws}

Document and work package reviews may involve a NEPA screening and/or the review and screening of associated laws, such as the National Historic Preservation Act of 1966 and the Endangered Species Act of 1973, and a cultural resource review. Most routine work in the tank farms is covered by U.S. Department of Energy categorical exclusion for routine maintenance. Work that is not routine undergoes NEPA screening in accordance with procedure RPP-PRO-452, NEPA, SEPA, Cultural and Natural Resources.

Two recent environmental impact statements, DOE/EIS-0189, Tank Waste Remediation System, Hanford Site, Richland, Washington, Final Environmental Impact Statement (DOE and Ecology 1996), and DOE/EIS-0212, Final Environmental Impact Statement, Safe Interim Storage of Hanford Tank Wastes (Ecology and RL 1995), address the environmental impacts of continued safe management and future disposal of RPP tank waste.

4.1.1.1 National Historic Preservation Act of 1966. In support of the National Historic Preservation Act of 1966, the U.S. Department of Energy (DOE), Richland Operations Office (RL) entered into a programmatic agreement with the Washington State Historic Preservation Office (DOE/RL-96-77, Programmatic Agreement Among the U.S. DOE-RL, the Advisory Council on Historic Preservation, and the Washington State Historic Preservation Office for the Maintenance, Deactivation, Alteration and Demolition of the Built Environment on the Hanford Site [RL 1996]). The agreement commits the Site to completing data collection and development of historical property inventory forms or extended historical property inventory forms for 10 RPP facilities. The facilities were selected for their historical contribution, unique construction, or process application. The 10 facilities are as follows:

- 209-E/200 East Area, Critical Mass Laboratory 
- 218-E-16/200 East Area, Grout Vault

- 241-AW/200 East Area, a DST farm

- 241-T/200 West Area, an SST farm

- 241-TX/200 West Area, an SST farm

- 241-TY/200 West Area, an SST farm

- 242-T/200 West Area, Evaporator

- 244-UR/200 West Area, Waste Disposal Vault

- 2707-AR/200 East, Change House.

4.1.1.2 Cultural Resource Review. The DOE approved a cultural resources exemption for the 18 RPP tank farms in 1994 (letter 9405630, Cultural Resources Exemption of the Tank Farm Areas [Crist 1994]). The basis for this exemption was the extensive disturbance caused by the installation of 177 DSTs and single-shell tanks (SST). The exemption covers construction and maintenance performed within $150 \mathrm{~m}(500 \mathrm{ft})$ of the 18 fenced tank farm areas and includes relocation of mobile offices. The exemption does not cover removal of tanks or demolition of permanent structures.

Excavation permits are required for activities that use mechanical means to dig below grade and for hand digging greater than $30 \mathrm{~cm}(12 \mathrm{in}$.) in depth. The excavation permit process requires a cultural resources review for projects not covered by the exemption.

Cultural resource reviews are conducted by the Hanford Cultural Resources Laboratory, Pacific Northwest National Laboratory (PNNL).

\subsubsection{Endangered Species Act of 1973. Title 50, Code of Federal Regulations (CFR),} Part 17, "Endangered and Threatened Wildlife and Plants," specifies the requirements for conducting reviews to determine whether a proposed project will have an impact on specialstatus plant and animal species. A blanket biological review is conducted annually for general maintenance activities inside the 200 East Area and 200 West Area tank farms. The objective of the review is to identify plant and animal species protected under the Endangered Species Act of 1973; candidates for protection and species listed as threatened, endangered, candidate, sensitive, or monitor species by the State of Washington; and species protected under the Historic Migratory Bird Treaty Act of 1918. Recommendations are generally limited because of the highly disturbed nature of the area, but some recommendations are provided relative to protection of bird species.

Biological reviews are required as part of the excavation permit process for activities not covered in the annual biological review process. Biological reviews are performed by PNNL.

\subsubsection{Environmental Monitoring}

Environmental monitoring identifies the impacts of Hanford Site operations on the environment. Results from (1) facility-effluent monitoring (2) near-field monitoring, (3) far-field monitoring, (4) groundwater monitoring and (5) the Groundwater/Vadose Zone Integration Project are annually documented in PNNL's Hanford Site environmental report. Facility-effluent monitoring for RPP facilities is performed by the RPP either at the facility or at the point of release to the environment. Near-field monitoring is conducted in the environment near facilities 
that discharge, or have discharged, effluents. Far-field monitoring consists of sampling and analyzing environmental media on and off the Hanford Site to assess the environmental impacts of contaminants originating from Site operations. Groundwater monitoring analyzes data from 700 wells to determine the distribution of radiological and chemical constituents in Hanford Site groundwater. The Groundwater/Vadose Zone Integration Project assesses the impacts of Hanford Site contaminants in the vadose zone, in groundwater beneath the Hanford Site, and on the Columbia River.

4.1.2.1 Facility-Effluent Monitoring. Liquid and airborne effluents that may contain radioactive or hazardous constituents are monitored. The RPP performs monitoring mainly through analyzing samples collected near points of release into the environment. Facility Effluent Monitoring Plan for the Tank Farm Facility, HNF-EP-0479-2 (FEMP) (Crummel 1998) meets the requirements of DOE/RL-91-50, Environmental Monitoring Plan, US Department of Energy, Richland Operations Office (RL 1997), as required by DOE Order 5400.1, General Environmental Protection Program, for operations involving hazardous materials and radioactive substances that could impact employee or public safety or the environment. The tank farm FEMP describes airborne effluent pathways and discharge points and associated sampling and monitoring systems, provides information on effluent characteristics, and lists conditions and requirements for monitoring to maintain and assess compliance with DOE orders, Federal, state, and local laws, regulations, and permits. The FEMP ensures long-range integrity of the effluentmonitoring systems by requiring updates whenever new processes or operations introduce new hazardous materials or significant radioactive materials. The RPP Environmental organization reviews the FEMP annually and updates it a minimum of every three years.

4.1.2.2 Near-Field Monitoring. The near-field environmental monitoring program is designed to protect the environment adjacent to facilities and to ensure compliance with regulations. The program monitors new and existing sites, processes, and facilities for potential impacts and releases, including fugitive emissions and diffuse sources from contaminated areas.

The environmental media sampled as part of the monitoring program include air, surface water and springs, surface contamination, soil, vegetation, and wildlife. Radioactivity in air is sampled by a network of continuously operating samplers near nuclear facilities. Soil and vegetation samples are collected on or adjacent to waste-disposal units and from locations downwind or near operating facilities. These samples are collected to detect potential migration and deposition of facility effluents. External radiation fields are measured near tank farm facilities and other waste-handling, storage, and disposal sites to measure, assess, and control the impacts of operations. Investigative sampling may be conducted to confirm the absence or presence of radioactive or hazardous contaminants near facilities such as storage and disposal sites. Investigative sampling is often used (1) as a follow-up to radiological surveys, (2) to conduct preoperational surveys before construction or operations, (3) to quantify the radiological condition of a site before remediation, or (4) to determine the integrity of waste-containment systems.

4.1.2.3 Far-Field Monitoring. Far-field monitoring at the Hanford Site includes monitoring environmental media on and off the Site for potential chemical and radiological contaminants originating from Site operations. 
The program includes sampling and analyses of the following environmental media to investigate the impacts of Hanford Site operations.

- Radioactive materials in air are continuously sampled at onsite locations, at the site perimeter, and in nearby and distant communities.

- Water samples of the Columbia River are taken at various locations to determine compliance with applicable standards. Water also is collected from onsite ponds located near operational areas. These ponds, although not accessible to the general public, are accessible to migratory waterfowl and other animals that can be a potential biological pathway for dispersal of onsite pond contaminants. Drinking water is monitored to verify that water quality on the Site complies with regulatory requirements.

- Milk, vegetables, fruit, alfalfa, and wine are collected from areas around the Site and analyzed for selected radionuclides.

- Fish and wildlife are sampled to investigate the accumulation of radionuclides and metals in animal tissue.

- Soil and vegetation samples are collected for special surveillance activities in association with cleanup activities.

- External radiation surveillance measures the radiological dose rates at both onsite and offsite locations.

The far-field monitoring program is conducted by PNNL.

4.1.2.4 Groundwater Monitoring. The Hanford Groundwater Monitoring Project is responsible for groundwater surveillance and monitoring activities, including Sitewide groundwater monitoring and near-field groundwater monitoring, to ensure that operations in and around waste-disposal facilities comply with applicable regulations.

Monitoring of radiological and chemical constituents in groundwater at the Hanford Site is performed (1) to characterize physical and chemical trends in the flow system, (2) to establish groundwater quality baselines, (3) to assess groundwater remediation, and (4) to identify new or existing groundwater problems. Samples are collected from 700 wells to determine the distribution of radiological and chemical constituents in Hanford Site groundwater. Monitoring verifies compliance with applicable environmental laws and regulations.

4.1.2.5 Hanford Groundwater/Vadose Zone Integration Project. The purpose of the Groundwater/Vadose Zone Integration Project is to assess the impacts of Hanford Site contaminants in the vadose zone, in groundwater beneath the Hanford Site, and on the Columbia River. Bechtel Hanford, Inc., has been assigned the lead responsibility as the project management contractor to achieve groundwater/vadose zone objectives. PNNL and Fluor Hanford are key members of the project team.

The project is based on the following: 
HNF-1773 Rev, 2

- Coordination and integration of Hanford Site work activities that are associated with the groundwater, vadose zone, or Columbia River to reduce cleanup costs, eliminate duplicate work, and determine where more information is needed to make better cleanup decisions

- Assessment of impacts of Hanford Site wastes on the land and people

- Application of sound science and technologies when making cleanup decisions, followed by independent technical review to ensure the technical defensibility of decisions and actions

- Building trust and partnering with the regulators, tribal nations, and stakeholders.

\subsubsection{Spill and Release Reporting}

The RPP meets the requirement for regulatory reporting of spills through HNF-IP-0842, RPP Administration, Volume VI, Section 1.3, "Environmental Notification" (LMHC 1999), The RPP personnel, predominately in operations, are required to report all spills and releases, with the exception of drips that can be immediately wiped up, to RPP Environmental in accordance with a published on-call list. The RPP Environmental personnel decide the reporting status of the spill or release and report it to the appropriate regulatory agencies and DOE. The RPP maintains a spill log. Spills that are not reportable to regulatory agencies are recorded in this $\log$.

\subsubsection{Chemical Management}

Environmental impacts are mitigated through the management of chemicals (hazardous, radioactive, and nonhazardous). The RPP procedure RPP-PRO-2258, Chemical Management, establishes the program that controls chemical usage; protects personnel, the public, and the environment from the hazards of chemicals; and is compliant with applicable regulatory requirements.

The Chemical Management System is a set of requirements applied to an activity, using a graded approach that is based on the complexity of operations and the nature and severity of associated impacts. The requirements are used to (1) evaluate the adequacy of chemical-management programs, (2) identify opportunities for improvement in the safe and efficient management of chemicals, (3) implement changes to existing chemical-management programs, (4) develop Chemical Management System requirements where appropriate, and (5) control the day-to-day management of chemicals on the Hanford Site. The day-to-day management of chemicals in the RPP includes control of hazardous chemical purchases by checking other site locations for available chemicals, review of purchase orders by hazardous material specialists, and substitution of less hazardous chemicals. 


\subsubsection{Pollution Prevention and Waste Minimization Program}

The purpose of the Hanford Site Pollution Prevention/Waste Minimization Program is to eliminate or reduce waste generation and pollutant releases to the environment, to reduce the use of toxic substances, and to conserve resources.

The RPP develops and implements the Pollution Prevention/Waste Minimization Program. The program includes the use of nonregulated products when possible, substitution of less hazardous products, source reduction, waste segregation of hazardous and nonhazardous material, goal setting for pollution prevention, and participation in pollution-prevention-opportunity assessments.

Environmental impacts of RPP activities are identified and minimized through implementation of the Pollution Prevention/Waste Minimization Program, specifically through the use of the waste-planning checklist. During work planning, the waste-planning checklist is prepared by the work planner and signed by a hazardous-material specialist. The checklist ensures that the waste generated during the proposed activity is identified and that proper handling instructions are provided before the start of work. The waste-planning checklist provides a means to document solid-waste generation and the method by which the waste will be disposed of. A new checklist is completed for each work package unless an existing generic checklist is used. A generic checklist may be developed for a repetitive job that has more than one work package.

Goals for RPP pollution prevention are established each fiscal year. Current goals for the RPP are as follows:

- Reduce the RPP hazardous-chemical inventory by three percent through the use of source reduction and recycling

- Review past pollution-prevention-opportunity assessments for missed implementation opportunities

- Conduct one pollution-prevention-opportunity assessment.

A pollution-prevention-opportunity assessment is an evaluation and/or appraisal of a process, activity, or operation to identify potential waste-minimization opportunities. Pollutionprevention opportunities may include (1) modifying a process to reduce dangerous or radioactive waste generation; (2) substituting materials to reduce chemical use or release; (3) substituting materials to reduce dangerous and radioactive waste generation; (4) reusing or recycling dangerous and radioactive wastes; or (5) encouraging the purchase and use of recovered/recycled materials. The RPP maintenance, operations, and radiological control organizations are invited and encouraged to participate in the assessments.

\subsubsection{Waste-Generation Tracking and Reporting}

The RPP manages satellite accumulation areas, waste-generating activities, and satellite inspections and provides access to Waste Management Federal Services of Hanford, Inc. (WMH) for delivery and pickup of containers. The WMH is responsible for the operation and 
management of the less-than-90-day pads and low-level-waste/transuranic management areas at the 209-E Building. WMH develops portfolios, performs any necessary waste sampling and field verification, and schedules shipments to treatment, storage, and disposal (TSD) facilities. The RPP provides oversight for these waste-management activities.

HNF-IP-0842, Volume VI, Section 4.1, "Waste Generating Plan" (LMHC 1999), contains the requirements for the generation of waste. All maintenance or modification work packages must be reviewed for waste generation before the work package is approved. The pre-job waste assessment is performed using a checklist from the "Waste Generating Plan." The wasteplanning checklist identifies the types of waste expected to be generated and the correct package and packaging for the waste. This ensures that potential waste is identified and the proper disposal package is available before the activity starts.

The RPP Environmental organization annually tracks actual radioactive, mixed, and hazardous waste generated and shipped versus estimated generation rates. The information is used for pollution-prevention-opportunity assessments conducted against various waste streams within the RPP. Cost-effective recommendations resulting from the assessments are implemented.

\subsection{IDENTIFICATION OF ENVIRONMENTAL REQUIREMENTS}

Environmental requirements are identified and managed in existing RPP permits and regulatory agreements as well as through the RPP S/RID (Biebesheimer 1996).

\subsubsection{Existing Permits and Regulatory Agreements}

4.2.1.1 Resource Conservation and Recovery Act of 1976. Ecology and the EPA issued WA7890008967, Hanford Facility RCRA Permit (Ecology and EPA 1994), which contains requirements for final status TSD units at the Hanford Site. The Hanford Site is considered a single RCRA facility with numerous TSD units.

\subsubsection{Hanford Federal Facility Agreement and Consent Order for NESHAP Compliance.} The RPP has several designated and nondesignated emission stacks. The RPP, like other Site projects, is not in compliance with "National Emission Standards for Hazardous Air Pollutants" (NESHAP) (40 CFR 61) monitoring requirements for many of the major emission stacks and, therefore, entered into the Federal Facility Agreement and Consent Order for NESHAP Compliance (EPA 1994). The consent order outlines the schedule for emission-stack monitoring upgrades that is necessary to achieve compliance. The NESHAP consent order (EPA 1994) is referenced in HNF-AOP-97-1, Hanford Site Air Operating Permit, Proposed Draft for Public Comment (FDH 1998). The RPP emission stacks are listed in Table 1. 
Table 1. River Protection Project Emission Stacks.

\begin{tabular}{|c|c|c|c|c|c|}
\hline Number & Tocilith & Sumber & Facing & Numbor & Facility \\
\hline \multicolumn{6}{|c|}{ River Protection Project Major Stacks - NESHAP Compliant } \\
\hline 296-A-12 & 244-AR Vessel Vent & |296-A-42 & $\begin{array}{l}\text { Aging Waste Project } \\
W-030\end{array}$ & 296-C-06 & $241-\mathrm{C}-106$ \\
\hline $296-U-11$ & 244-U DCRT & & & & \\
\hline \multicolumn{6}{|c|}{ River Protection Project Major Stacks - Addressed in NESHAP Compliance Agreement (EPA 1994) } \\
\hline 296-A-17 & $\begin{array}{l}\text { AY/AZ Primary } \\
\text { Tank }\end{array}$ & |296-P-26 & $\begin{array}{l}\text { AY/AZ Tank } \\
\text { Backup Ventilation }\end{array}$ & 296-A-25 & 244-A DCRT \\
\hline 296-B-28 & 244-BX DCRT & $296-\mathrm{C}-5$ & 244-CR Vault & 296-P-16 & 241-C-105/6 Tanks \\
\hline $296-S-22$ & 244-S DCRT & 296-T-18 & 244-TX DCRT & & \\
\hline \multicolumn{6}{|c|}{ Fiver Protection Project Minor Stacks } \\
\hline $296-A-13$ & $\begin{array}{l}\text { 244-AR Cell and } \\
\text { Canyon }\end{array}$ & 296-A-18 & $\begin{array}{l}\text { 241-AY-101 } \\
\text { Annulus }\end{array}$ & 296-A-19 & $\begin{array}{l}\text { 241-AY-102 } \\
\text { Annulus }\end{array}$ \\
\hline 296-A-20 & $\begin{array}{l}\text { 241-AZ-101/102 } \\
\text { Annulus }\end{array}$ & 296-A-26 & $\begin{array}{l}\text { 204-AR Rail Car } \\
\text { Unloading }\end{array}$ & 296-A-27 & AW Primary Tanks \\
\hline 296-A-28 & AW Annuli & 296-A-29 & AN Primary Tanks & 296-A-30 & AN Annuli \\
\hline $296-A-40$ & AP Primary Tanks & 296-A-41 & AP Annuli & 296-A-43 & $\begin{array}{l}\text { Aging Waste } \\
\text { Building (W-030) }\end{array}$ \\
\hline 296-C-07 & $\begin{array}{l}\text { 241-C-103 Vapor } \\
\text { Mixer System }\end{array}$ & 296-P-22 & SY Annuli & 296-P-23 & SY Primary Tanks \\
\hline 296-S-25 & $\begin{array}{l}\text { SY Replacement } \\
\text { Exhauster }\end{array}$ & |296-P-31 & 209-E Building & 296-P-32 & 244-AR Vessel Vent \\
\hline 296-P-33 & RMCS \#3 & $296-P-34$ & RMCS \#4 & 296-S-15 & RMCS in SX Farm \\
\hline $\begin{array}{l}296-\mathrm{P}-35 \\
\text { through } \\
296-\mathrm{P}-40\end{array}$ & Blue Max & 296-P-41 & $\begin{array}{l}\text { 241-A-101 Portable } \\
\text { Exhauster }\end{array}$ & $296-S-15$ & SX Tanks \\
\hline 296-S-18 & 242-S Evaporator & 296-T-17 & 242-T Evaporator & 296-W-03 & $\begin{array}{l}\text { 213-W Waste } \\
\text { Compactor }\end{array}$ \\
\hline
\end{tabular}

EPA, 1994, Federal Facility Agreement and Consent Order for NESHAP Compliance, U.S. Environmental Protection Agency, Seattle, Washington.

DCRT = double-contained receiver tank.

NESHAP = National Emission Standards for Hazardous Air Pollutants.

RMCS = rotary mode core sampling. 
4.2.1.3 Hanford Site Air Operating Permit. The Hanford Site is required to submit an application and receive an approved air operating permit (AOP). The Hanford Site submitted an AOP application to Ecology in 1995. The AOP application has been amended/supplemented on a regular basis. Ecology will issue a draft AOP for public comment. At the completion of this process Ecology will issue a Hanford Site AOP.

The RPP receives multiple regulatory approvals each year for air emissions related to construction or new projects. The RPP approval information is maintained in HNF-4474, RPP Environmental Permits and Related Documentation (Dexter 1999).

4.2.1.4 Discharge Permits. Wastewater discharges, including cooling water and condensate discharges from systems like air compressors, diesel engines, air conditioning, ventilation, evaporative cooling, ice machines, steam lines, and other miscellaneous discharges from pump leaks, valve wastewater, water tank overflows, and quench tanks are permitted to be discharged to the ground via infiltration in accordance with the conditions in State Waste Discharge Permit, Cooling Water and Condensate Discharge, ST-4509 (Ecology 1998a). Source waters are limited to ensure that discharges meet Washington Administrative Code (WAC) 173-200, "Water Quality Standards for Ground Waters of the State of Washington." The only source waters to be used by cooling water and condensate discharge activities are raw Columbia River water, raw groundwater, potable water or condensed water vapor from ambient air.

Maintenance (drainage and flushing activities), hydrotesting, and construction (concrete curing and pressure washing) activities are permitted to discharge to the ground via infiltration in accordance with the conditions of State Waste Discharge Permit, Hydrotest, Maintenance, and Construction, ST-4508 (Ecology 1998b). Source waters are limited to ensure that discharges meet WAC 173-200. The only source waters to be used by hydrotest, maintenance, and construction activities are raw Columbia River water, potable water, or treated potable water.

State Waste Discharge Permit, Industrial Stormwater Discharges, ST-4510 (Ecology 1999), authorizes industrial storm water discharges to ground, which are collected in engineered structures such as lined trenches, basins, retention structures, secondary containment structures, tanks, sumps, roofs, parking lots, and other impervious surfaces directly associated with industrial activities and then discharged to engineered disposal structures such as injection wells, dry wells, catch basins, infiltration basins, and infiltration trenches.

4.2.1.5 Underground Storage Tank Management. The RPP operates one underground diesel fuel tank system subject to the requirements of WAC 173-360, "Underground Storage Tank Regulations." The underground storage tank system for the 204-AR Waste Unloading Facility meets the material, design, corrosion, leak detection, spill, and overfill requirements of this regulation.

4.2.1.6 As-Low-As-Reasonably-Achievable Control-Technology Demonstrations. The RPP Environmental organization participated in as-low-as-reasonably-achievable controltechnology (ALARACT) demonstration partnering sessions with Fluor Hanford, RL, and WDOH. The purpose of the sessions was to document routine activities conducted within tank farm facilities. The ALARACT demonstrations do not cover new activities, modifications, construction, or decontamination and decommissioning activities. Fourteen ALARACT demonstrations were negotiated as routine operations for tank farms. Each ALARACT 
demonstration consists of the activity description and associated radiological controls, monitoring, and record requirements. These were issued in HNF-4327, Rev. 0c, Control of Airborne Radioactive Emissions for Frequently Performed TWRS Work Activities (ALARACT Demonstrations) (Dyekman 2000).

The 14 activities are as follows:

- Riser preparation/opening

- Installation/operation/removal of push-mode core-sampling equipment

- Installation/operation/removal of auger sampling equipment

- Packaging and transportation of waste

- Soil excavation (using hand tools)

- Pit access

- Tank-waste grab sampling

- Vapor sampling

- Light-duty utility arm (passive)

- Water lancing

- Waste transfers

- Packaging and transportation of equipment and vehicles

- Installation, operation, and removal of tank equipment

- Pit work

- Size reduction of waste equipment for disposal.

\subsubsection{Environmental Requirements Management}

Integration of applicable environmental requirements with current and planned RPP activities is necessary to satisfy legal and contractual commitments and is important to the implementation of a comprehensive environmental program. These requirements are integrated into work planning and execution in accordance with the RPP ISMS Plan (RPP-MP-003). Compliance of the RPP with applicable environmental regulations is dependent on having a structured approach to evaluating new and existing environmental requirements. The environmental requirements applicable to the RPP become part of the RPP S/RID (Biebesheimer 1996).

\subsubsection{River Protection Project Standards and Requirements Identification Document.} The RPP environmental requirements process is based on the Tank Farms Nuclear Facilities S/RID, Section 13, "Packaging and Transportation," Section 16, "Waste Management," and Section 20, "Environmental Protection" (Biebesheimer 1996). The process is outlined in procedure HNF-IP-0842, Volume VI, Sec 2.2, "Environmental Requirements Management" (LMHC 1999).

The Environment, Safety, and Health standards and requirements in the RPP contract may be superceded, in whole or in part, by an alternative set of requirements developed through the S/RID process. The S/RID provides a standards baseline and allows for tracking and amending requirements. Requirements-basis configuration control ensures that the S/RID and procedures stay current with regulatory changes. The RPP must comply with policies and procedures for 
requirements contained in the RPP S/RID (Biebesheimer 1996) and the ISMS Plan (RPP-MP-003).

When an environmental requirement is applicable to the RPP, the RPP interpretive authority will inform the S/RID coordinator. Documentation to modify the S/RID and incorporate the change will be processed through the S/RID coordinator. The Office of River Protection approves any permanent changes to the requirements governing the RPP. Annual updates are submitted to the Office of River Protection. Quarterly updates may be provided to incorporate changes in the requirements as needed. The interpretive authority will help determine the implementing process for the new requirement and will ensure that implementing documentation resulting from the S/RID change is updated. 
HNF-1773 Rev. 2

This page intentionally left blank. 


\subsection{ANALYZE HAZARDS AND ENVIRONMENTAL IMPACTS AND IMPLEMENT CONTROLS}

Identification of environmental impacts and hazards is essential to establish effective work controls and provide for the safe performance of work. Identification of impacts and hazards and implementation of controls are completed during the work-planning process. The RPP Environmental organization is involved in work planning at two levels: the project level and the activity level. At the project level, environmental support is identified and quantified. At the activity level, environmental impacts and hazards are identified and controlled.

\subsection{WORK-PLANNING PROJECT LEVEL}

The project representative develops the scope and planned schedule for the proposed project and provides this information to RPP Environmental. The RPP Environmental organization prepares an environmental planning package consisting of a summary of applicable permits and approvals, the permitting strategy, the cost estimate, and schedules. For larger and more complex projects, an Environmental permits and approvals plan is prepared. The RPP Environmental organization will develop an estimate of environmental resources necessary to support the project scope. The package or plan and the resources estimate are forwarded to the project representatives for review and comment. The final package or plan is reviewed and accepted by RPP Environmental.

The project representative incorporates the environmental planning information into the technical-basis review process to ensure that appropriate funding is allocated for environmental support.

The RPP Environmental organization periodically reviews the subject environmental planning package or plan to ensure the continuing accuracy of the information.

\subsection{WORK-PLANNING ACTIVITY LEVEL}

The RPP Environmental organization's involvement with activity-level planning consists of work-package reviews and participation in enhanced work-planning sessions.

Automated job-hazards analysis is a tool used by RPP job planners and cognizant engineers in accordance with RPP procedure RPP-PRO-079, Job Hazard Analysis. It is used when constructing a work package to identify, evaluate, control, and communicate potential hazards and environmental impacts associated with routine and nonroutine operations. The cognizant engineer or technical authority identifies the appropriate approval designators for document review (e.g., reports, procedures, work packages), in accordance with the guidance in RPP procedure RPP-PRO-233, Review and Approval of Documents. Low-risk, routine work typically does not require a job-hazard analysis or an "E" approval (an environmental review) unless the activity has the potential for environmental impacts. If an "E" approval is required, RPP environmental personnel, typically the environmental-compliance officer or delegate, perform a review of the work package to identify potential environmental issues in areas such as waste management, release potential, NEPA impacts, etc. Comments are forwarded to the cognizant 
engineer and/or job planner regarding the environmental requirements for the work in question. Adequate controls are then added to the work package to incorporate environmental regulatory requirements. Through compliance with applicable regulatory requirements, impacts to the environment are mitigated.

Nonroutine activities that have a higher potential for environmental/radiological/safety impacts are typically addressed in enhanced work-planning sessions. Enhanced work-planning sessions include planning, engineering, operations, crafts, environmental, safety, and quality assurance personnel to plan work (including hazard and environmental-impact identification, evaluation, and control using job-hazard analysis) and develop the work package for the activity. Controls to minimize impacts to health, worker safety, and the environment are discussed and incorporated into the work package.

\subsection{RIVER PROTECTION PROJECT PROJECTS AND ACTIVITIES: INTEGRATED PERMITTING SCHEDULE}

The RPP Environmental ensures that appropriate environmental permits are prepared for RPP activities and projects. An RPP integrated environmental schedule has been prepared based on a review of planned activities for RPP programs and projects. The schedule identifies current and upcoming environmental permits and approvals and is being uploaded into the Sitewide integrated permitting schedule.

\subsubsection{Resource Conservation and Recovery Act of 1976 Permit}

The RCRA permitting for the RPP is completed in accordance with schedules found in the Hanford Federal Facility Agreement and Consent Order (Tri-Party Agreement) (Ecology et al.1996) Action Plan and the Hanford Facility RCRA Permit (Ecology and EPA 1994).

There are two options for bringing a TSD unit into compliance: one for final status and one for closure. An individual dangerous-waste permit application or closure plan has been or will be submitted for each TSD unit. The RPP Environmental organization is responsible for maintaining RPP Part A permit applications and preparing Part B permit applications.

The RPP operates RCRA facilities under interim-status requirements and the Tri-Party Agreement (Ecology et al. 1996) and is in the process of revising the Part B permit application for the DST system (RL 1993), which includes the 204-AR Waste Unloading Facility. The HNF-SD-WM-EV-053, Double-Shell Tank Waste Analysis Plan (Mulkey 1998), is used to ensure the collection of adequate information for the safe handling of waste entering the DST system. The Plan relies on documents like HNF-SD-WM-DQO-001, Rev. 3, Data Quality Objectives for Tank Farms Waste Compatibility Program (Mulkey 1999) to determine what information is required for safe handling of the incoming waste. Waste transfers from non-tank farm facilities are evaluated to ensure compliance. Each generator must provide a waste profile that documents waste composition and identifies applicable regulatory requirements. 
For the RPP TSD units that cannot be operated in compliance with interim-status standards, identified actions necessary to bring the TSD units into compliance are located in Appendix D of the Tri-Party Agreement (Ecology et al. 1996). A closure plan must be developed and submitted for each unit before it is closed. The SST system is pursuing this path.

\subsubsection{Notice of Construction Applications}

The RPP Environmental organization develops, or directs the development of, radioactive and nonradioactive air emission permits needed to conduct non-routine maintenance, operations, characterization activities, and new projects.

The WDOH administers the Radioactive Air Emissions Program as stated in WAC Chapters 246-247, "Radiation Protection--Air Emissions." Approval to construct must be obtained before construction or facility modification and must address WAC 246-247-110, Appendix A, "Application Information Requirements." Frequently performed activities are not considered to be facility modifications and, therefore, do not require notice of construction (NOC) approval (see Section 4.2.1.6).

The EPA administers the NESHAP program in the State of Washington in accordance with 40 CFR 61, "National Emission Standards for Hazardous Air Pollutants," Subpart H, "National Emission Standards for Emission of Radionuclides Other Than Radon From DOE Facilities." The permitting process is the same as that specified in the WDOH NOC approval process. Specific background documentation requirements for the approval to construct include engineering studies, functional-design criteria, conceptual-design reports, and advanced conceptual-design reports; and supporting documentation may include source-term estimates, emissions estimates, and design information.

An NOC approval is required from Ecology before the establishment of any new source or emission unit or modification that increases the amount of any toxic air pollutant emitted or that results in the emission of any toxic air pollutant not previously emitted. Ecology administers the program in accordance with WAC 173-460, "Controls for New Sources of Toxic Air Pollutants." Criteria pollutants also may require an Ecology approval under WAC 173-400, "General Regulations for Air Pollution Sources."

\subsection{IMPLEMENTATION OF PERMIT CONDITIONS}

As permit conditions are imposed on the RPP, and as new or changed regulations become effective, the RPP Environmental organization will work with the affected organization to properly implement the new requirements (for a current listing of all environmental permits applicable to the RPP, see Dexter [1999]). The RPP Environmental organization also will initiate modifications to the facility's S/RID (Biebesheimer 1996).

Field implementation of air-permit-related regulatory approvals is governed by HNF-IP-0842, Volume VI, Section 1.2, "Field Implementation of Environmental Notices of Construction for Air Emission Units Operated by RPP" (LMHC 1998). The procedure describes the process necessary to ensure proper field implementation of NOC requirements and approval conditions for air emission units operated by the RPP. According to procedure, environmental personnel 
HNF-1773 Rev. 2

will develop a compliance matrix for each NOC, perform compliance assessments, conduct technical briefings for operations personnel, provide field assistance as needed, perform a quarterly review of actual emissions, and assist operations in incorporating NOC requirements and conditions into procedures and work packages. 


\subsection{PERFORM WORK WITHIN CONTROLS}

Performing work includes preparing for the work, confirming readiness to perform the work, and then performing the work in a safe and environmentally protective manner.

\subsection{EMPLOYEE TRAINING AND QUALIFICATION PROGRAM}

Facility- and job-specific training is provided by the RPP in accordance with HNF-SD-WM-TR-026, Tank Waste Remediation System Dangerous Waste Training Plan (Pohto 1999a) for compliance with the training requirements of WAC 173-303, Section 330, "Personnel Training." Job-specific training is identified in HNF-IP-0974, River Protection Project Dangerous Waste Training Requirements Matrices (Pohto1999b). The plans address training requirements for personnel working at the RPP managed TSD-unit facilities in the 200 East Area, 200 West Area, and 600 Area.

The RPP training program is designed to prepare employees to operate and maintain the tank farms in a safe, effective, efficient, and environmentally sound manner. In addition to preparing employees to operate and maintain the tank farms under normal conditions, the training program ensures that employees are prepared to respond in a prompt and effective manner, should abnormal or emergency conditions occur. Emergency-response training is consistent with emergency responses outlined in the building emergency plans.

The RPP requires technical staff authorized to provide environmental approvals to undergo a qualification program as described in HNF-IP-0842, Volume III, Section 10.3, "Technical Staff Qualification Program Description" (LMHC 1999). This qualification program will ensure that technical staff personnel possess the knowledge and skills necessary to perform their assigned duties in a safe, efficient, and cost-effective manner. The facility environmental-professional qualification process ensures that candidates can demonstrate knowledge of environmentspecific requirements (i.e., air emissions, NEPA, Tri-Party Agreement [Ecology et al. 1996]) and can demonstrate the ability to perform specific environmental work tasks (e.g., perform satellite accumulation areas assessment, NEPA screening, work-package review, facility walkdowns). Possession of the Environmental Professional Qualification Card provides authorization for the owner to conduct environmental reviews and to give approvals for RPP work activities.

\subsection{CONFIRMING READINESS TO PERFORM THE WORK}

The RPP Environmental organization participates in operation readiness reviews, readiness assessments, pre-job briefings, and other meetings to provide evidence that the environmental program is sufficient for the program, project, or activity to proceed without compliance issues. The evidence provided can be via formal affidavit as required by an operation readiness review or a discussion of the compliance matrix (see Section 5.4) during a less formal pre-job briefing. 


\subsection{PERFORMING WORK}

Performing work in a compliant manner involves maintaining and storing environmental records and submitting various environmental reports.

As work is performed, environmental records are generated. Timely environmental record keeping and reporting is required to demonstrate regulatory compliance. Environmental regulations require that certain documents, procedures, and data are retrievable within specified periods of time. The RPP Environmental organization supports regulator requests for such records. In addition, the RPP is participating in a Sitewide initiative to scan these records into the Record Management Information System.

Environmental reports are required by various regulations. Generally these reports are Site wide in nature. The RPP Environmental organization prepares inputs to these reports. Appendix A of this document outlines the reports and the types of information required to be submitted by the Hanford Site. 
HNF-1773 Rev. 2

\subsection{PROVIDE FEEDBACK AND CONTINUOUS IMPROVEMENT}

The RPP Environmental organization verifies that RPP activities are conducted in an environmentally safe and sound manner and in compliance with applicable environmentalprotection program requirements through mechanisms that assess and measure performance.

\subsection{PERFORMANCE MEASURES}

Environmental goals and objectives have been established, and progress toward achieving them is monitored and measured. Current examples are listed below.

\subsubsection{Goal: Complete Radioactive and Nonradioactive Notices of Construction on Schedule.}

Permitting plans are updated and discussed with RPP Planning and Integration. Schedules provide feedback on how well the RPP Environmental organization is meeting permitting deadlines.

\subsubsection{Goal: Maintain an Efficient Environmental Oversight Program by Responding to Program Indicators.}

Deficiencies from assessments are categorized and tracked monthly. Feedback is used to plan and schedule the type, location, and frequency of future inspections.

\subsubsection{Goal: Reduce the Number of Regulatory Agency Findings.}

The number and location of regulatory visits and findings are recorded and tracked. Performance is measured by comparison of the number of visits to the number of findings.

\subsubsection{Goal: Meet All Tri-Party Agreement Milestone Commitments.}

Tri-Party Agreement milestones are tracked, and performance is based on commitment completion.

\subsection{ENVIRONMENTAL SURVEILLANCE PROGRAM}

The RPP Environmental organization maintains a multilevel environmental-compliance program that includes management assessments, worker assessments (surveillance/compliance inspections, functional assessments, and subcontractor assessments), independent assessments (Facility Evaluation Board), support of external audits (state and Federal agencies), commitment tracking, and occurrence trending. 


\subsubsection{Management Assessments}

Senior management involvement and review is crucial to successful operation of the feedback and improvement function. The RPP Environmental organization management participates in management assessments in accordance with procedure HNF-IP-0842, Vol. I, Section 2.10, "Management Assessment Program" (LMHC 1999). A management assessment is defined in this procedure as "An evaluation of management processes performed by or for the manager to determine compliance to and effectiveness of implementation of program requirements." This procedure also provides for an integrated and prioritized annual management program schedule approved by the appropriate management. The annual environmental functional-assessment schedule is integrated into the management-assessment schedule, and functional assessments meet the requirements of the management-assessment procedure.

\subsubsection{Surveillance/Compliance Inspections}

Surveillance/compliance inspections are performed by the RPP Environmental organization on a schedule developed annually. The frequency of surveillance is based on the potential environmental hazard at a facility and on past performance.

The surveillance/compliance inspection program is implemented under HNF-IP-0842, Volume VI, Section 2.1, "Scheduling, Planning, and Conducting Surveillance/Compliance Inspections" (LMHC 1999). Surveillance/compliance inspections of tank-farm facilities are conducted by Environmental personnel to verify compliance with requirements, assess corrective actions taken in response to previous deficiencies, and ensure that equipment necessary for environmental monitoring is maintained by the tank farm operations and maintenance organizations.

\subsubsection{Functional Assessments}

Environmental functional assessments are performed by the RPP Environmental organization, on an annual schedule. The frequency and subject matter of environmental functional assessments are determined using input from management directives, known or suspected noncompliances, and assessments necessary to complete S/RID Phase II evaluations (Biebesheimer 1996).

The functional-assessments program is implemented by the RPP Environmental organization under HNF-IP-0842, Volume VI, Section 2.3, "Planning, Preparing for, Conducting, and Reporting Functional Assessments" (LMHC 1999). Environmental functional assessments are planned and scheduled based on potential environmental concerns associated with RPP activities. The assessments are conducted by environmental personnel to verify that environmentalmanagement control systems have been implemented to maintain compliance with applicable environmental regulations and U.S. Department of Energy policies and objectives.

\subsubsection{Subcontractor Management Assessments}

To ensure the appropriate level of RPP-subcontractor awareness of environmental issues and regulations, the function of subcontractor management and oversight was established. The 
subcontractor management function includes (1) communication of requirements and (2) assessments, inspections, and/or surveillance to ensure subcontractor compliance with environmental requirements.

\subsubsection{Independent Assessments}

The RPP conducts a program of performance-based independent observation and evaluation of facilities, direct-support activities, and comprehensive reviews of the facility self-assessment process. This program is implemented in HNF-IP-0842, Vol. XI, Sec. 1.4, "RPP Independent Assessment Program" (LMHC 1999).

\subsubsection{External Audits}

The RPP Environmental personnel support external audits from WDOH, Ecology, EPA, DOE, and others. The deficiencies identified by agencies external to the RPP are documented and tracked through the implementation of Environmental Desk Instruction 7B200-99-051, RPP Environmental Corrective Action Management for External Deficiencies (LMHC 1999). This instruction requires that cognizant management be advised of deficiencies and provided with documentation indicating the origin of the deficiencies. The instruction also requires that all deficiencies be entered into the Deficiency Tracking System.

\subsection{COMMITMENT TRACKING AND OCCURRENCE TRENDING}

The RPP evaluates and tracks environmental deficiencies and corresponding corrective actions as per requirements contained in: RPP-PRO-653, Deficiency Tracking System; RPP-PRO-052, Corrective Action Management; HNF-IP-0842, Volume I, Section 2.4, "Corrective Action Management" (LMHC 1999); and Environmental Desk Instruction 7B200-99-051, TWRS Environmental Corrective Action Management for External Deficiencies (LMHC 1998).

The RPP Environmental organization maintains an independent database to trend deficiencies identified by oversight activities. A quarterly categorical grouping of deficiencies identifies which environmental media are of greatest concern. This information allows a focus of resources on problem areas and is applied to future oversight scheduling. 
HNF-1773 Rev. 2

This page intentionally left blank. 
HNF-1773 Rev. 2

\subsection{REFERENCES}

Acts

Endangered Species Act of 1973, as amended, 10 USC 1531 et seq.

Historic Migratory Bird Treaty Act of 1918, as amended, 16 USC 703 et seq.

National Environmental Policy Act of 1969, as amended, 42 USC 4321 et seq.

National Historic Preservation Act of 1966, as amended, 16 USC 470 et seq.

Resource Conservation and Recovery Act of 1976, as amended, 42 USC 6901 et seq.

\section{Code of Federal Regulations}

40 CFR 61, "National Emission Standards for Hazardous Air Pollutants," Code of Federal Regulations, as amended.

50 CFR 17, "Endangered and Threatened Wildlife and Plants," Code of Federal Regulations, as amended.

\section{U.S. Department of Energy Orders}

DOE Order 5400.1, General Environmental Protection Program, U.S. Department of Energy, Washington, D.C.

\section{Washington Administrative Code}

WAC 173-200, "Water Quality Standards for Ground Waters of the State of Washington," Washington Administrative Code, as amended.

WAC 173-303, "Dangerous Waste Regulations," Washington Administrative Code, as amended.

WAC 173-360, "Underground Storage Tank Regulations," Washington Administrative Code, as amended.

WAC 173-400, "General Regulations for Air Pollution Sources," Washington Administrative Code, as amended.

WAC 173-460, "Controls for New Sources of Toxic Air Pollutants," Washington Administrative Code, as amended.

WAC 246-247, "Radiation Protection - Air Emissions," Washington Administrative Code, as amended. 
HNF-1773 Rev. 2

\section{River Protection Project Policies and Procedures}

RPP-MD-023, Multi-Year Work Plan (MYWP) Scheduling, CH2M HILL Hanford Group, Inc., Richland, Washington.

RPP-MP-003, Integrated Environment, Safety, and Health Management System Plan, CH2M HILL Hanford Group, Inc., Richland, Washington.

RPP-PRO-052, Corrective Action Management, CH2M HILL Hanford Group, Inc., Richland, Washington.

RPP-PRO-079, Job Hazard Analysis, CH2M HILL Hanford Group, Inc., Richland, Washington.

RPP-PRO-233, Review and Approval of Documents, CH2M HILL Hanford Group, Inc., Richland, Washington.

RPP-PRO-452, NEPA, SEPA, Cultural and Natural Resources, CH2M HILL Hanford Group, Inc., Richland, Washington.

RPP-PRO-653, Deficiency Tracking System, CH2M HILL Hanford Group, Inc., Richland, Washington.

RPP-PRO-2258, Chemical Management, CH2M HILL Hanford Group, Inc., Richland, Washington.

\section{Documents}

Biebesheimer, E., 1996, High Level Waste Storage Tank Farms/242-A Evaporator Standards/Requirements Identification Document, WHC-SD-MP-SRID-001, Rev. 1B, Westinghouse Hanford Company, Richland, Washington.

Dyekman, D. L., 2000, Control of Airborne Radioactive Emissions for Frequently Performed TWRS Work Activities (ALARACT Demonstrations), HNF-4327, Rev. 0c, CH2M HILL Hanford Group, Inc., Richland, Washington.

Crist, M. E., 1994, Cultural Resources Exemption of the Tank Farm Areas (letter 9405630 to W. B. Bancroft, Westinghouse Hanford Company, August 16), U.S. Department of Energy, Richland Operations Office, Richland, Washington.

Crummel, G. M., 1998, Facility Effluent Monitoring Plan for the Tank Farm Facility, HNF-EP-0479-2, prepared by Lockheed Martin Hanford Corporation for Fluor Daniel Hanford, Inc., Richland, Washington.

Dexter, M. L., 1999, RPP Environmental Permits and Related Documentation, HNF-4474, Rev. 4, CH2M HILL Hanford Group, Inc., Richland, Washington.

DOE and Ecology, 1996, Tank Waste Remediation System, Hanford Site, Richland, Washington, Final Environmental Impact Statement, DOE/EIS-0189, U.S. Department of Energy and Washington State Department of Ecology, Washington, D.C. 
Ecology, 1998a, State Waste Discharge Permit, Cooling Water and Condensate Discharge, ST-4509, Washington State Department of Ecology, Olympia, Washington.

Ecology, 1998b, State Waste Discharge Permit, Hydrotest, Maintenance, and Construction, ST-4508, Washington State Department of Ecology, Olympia, Washington.

Ecology, 1999, State Waste Discharge Permit, Industrial Stormwater Discharges, ST-4510, Washington State Department of Ecology, Olympia, Washington.

Ecology and EPA, 1994, Hanford Facility RCRA Permit, WA7890008967, as modified, Washington State Department of Ecology and U.S. Environmental Protection Agency, Olympia, Washington.

Ecology and RL, 1995, Final Environmental Impact Statement, Safe Interim Storage of Hanford Tank Wastes, DOE/EIS-0212, Washington State Department of Ecology and U.S.

Department of Energy, Richland Operations Office, Lacey, Washington.

Ecology, EPA, and DOE, 1996, Hanford Federal Facility Agreement and Consent Order, Washington State Department of Ecology, U.S. Environmental Protection Agency, and U.S. Department of Energy, Olympic, Washington.

EPA, 1994, Federal Facility Agreement and Consent Order for NESHAP Compliance, U.S. Environmental Protection Agency, Seattle, Washington.

FDH, 1998, Hanford Site Air Operating Permit, Proposed Draft for Public Comment, HNF-AOP-97-1, Fluor Daniel Hanford, Inc., Richland, Washington.

LMHC, 1999, RPP Environmental Corrective Action Management for External Deficiencies, Environmental Desk Instruction 7B200-99-051, Lockheed Martin Hanford Corporation, Richland, Washington.

LMHC, 1999, RPP Administration, HNF-IP-0842, prepared by Lockheed Martin Hanford Corporation, Richland, Washington.

Volume I, Section 2.4, "Corrective Action Management"

Volume I, Section 2.10, "Management Assessment Program"

Volume III, Section 10.3, "Technical Staff Qualification Program Description"

Volume VI, Section 1.2, "Field Implementation of Environmental Notices of

Construction for Air Emission Units Operated by RPP"

Volume VI, Section 1.3, "Environmental Notification"

Volume VI, Section 2.1, "Scheduling, Planning, and Conducting

Surveillance/Compliance Inspections"

Volume VI, Section 2.2, "Environmental Requirements Management"

Volume VI, Section 2.3, "Planning, Preparing for, Conducting, and Reporting Functional Assessments"

Volume VI, Section 4.1, "Waste Generating Plan"

Volume XI, Section 1.4, "RPP Independent Assessment Program." 
Mulkey, C. H., 1998, Double-Shell Tank Waste Analysis Plan, HNF-SD-WM-EV-053, Rev. 5, prepared by Lockheed Martin Hanford Corporation for Fluor Daniel Hanford, Inc., Richland, Washington.

Mulkey, C. H., 1999, Data Quality Objectives for Tank Farms Waste Compatibility Program, HNF-SD-WM-DQO-001, Rev. 3, prepared by Lockheed Martin Hanford Corporation for Fluor Daniel Hanford, Inc., Richland, Washington.

Pohto, R. E., 1999a, Tank Waste Remediation System Dangerous Waste Training Plan, HNF-SD-WM-TR-026, Rev. 9, prepared by Lockheed Martin Hanford Corporation for Fluor Daniel Hanford, Inc., Richland, Washington.

Pohto, R. E., 1999b, River Protection Project Dangerous Waste Training Requirements Matrices, HNF-IP-0974, Rev. 18, Lockheed Martin Hanford Corporation, Richland, Washington.

RL, 1993, Hanford Facility Dangerous Waste Part A Permit Application, DOE/RL-88-21, 3 vols., U.S. Department of Energy, Richland Operations Office, Richland, Washington.

RL, 1996, Programmatic Agreement Among the U.S. DOE-RL, the Advisory Council on Historic Preservation, and the Washington State Historic Preservation Office for the Maintenance, Deactivation, Alteration and Demolition of the Built Environment on the Hanford Site, DOE/RL-96-77, U.S. Department of Energy, Richland Office, Richland, Washington.

RL, 1997, Environmental Monitoring Plan, United States Department of Energy, Richland Operations Office, DOE/RL-91-50, Rev. 2, U.S. Department of Energy, Richland Operations Office, Richland, Washington. 
HNF-1773 Rev. 2

APPENDIX A

INFORMATION NEEDED TO SUPPORT SITE WIDE REPORTING 
HNF-1773 Rev. 2

This page intentionally left blank.

A-ii 


\section{APPENDIX A \\ INFORMATION NEEDED TO SUPPORT SITE WIDE REPORTING}

\begin{tabular}{|c|c|c|c|}
\hline Report & Information needed & $\begin{array}{l}\text { Required by contract } \\
\text { or regulations }\end{array}$ & Certifications \\
\hline Annual LDR Report & $\begin{array}{l}\text { Waste inventories and narrative descriptions of } \\
\text { TSD units storing mixed LDR waste }\end{array}$ & TPA milestone M-26-01 & None \\
\hline $\begin{array}{l}\text { Hanford Site } \\
\text { Environmental Report }\end{array}$ & $\begin{array}{l}\text { Compliance with environmental regulations, } \\
\text { current site activities, accomplishments, and } \\
\text { issues. Releases of radionuclides in air/water, } \\
\text { hazardous substances, unplarned environmental } \\
\text { releases, inventories of chemicals, effluent } \\
\text { monitoring activities and environmental } \\
\text { surveillance activities. }\end{array}$ & DOE Order & None \\
\hline $\begin{array}{l}\text { EPCRA Tier II } \\
\text { Emergency and } \\
\text { Hazardous Chemical } \\
\text { Inventory }\end{array}$ & $\begin{array}{l}\text { Provide periodic input on inventory of hazardous } \\
\text { materials with annual verification/certification of } \\
\text { information. }\end{array}$ & Regulations & $\begin{array}{l}\text { Contractors- Internal } \\
\text { Certification } \\
\text { RL - Certification }\end{array}$ \\
\hline $\begin{array}{l}\text { EPCRA Toxic } \\
\text { Chemical Release } \\
\text { Inventory Report }\end{array}$ & $\begin{array}{l}\text { Annual input on use and releases of toxic } \\
\text { chemicals. }\end{array}$ & Regulations & $\begin{array}{l}\text { Contractors- Internal } \\
\text { Certification } \\
\text { RL - Certification }\end{array}$ \\
\hline $\begin{array}{l}\text { Annual Dangerous } \\
\text { Waste Report }\end{array}$ & $\begin{array}{l}\text { Provide information on waste generation and } \\
\text { waste management activities }\end{array}$ & Regulations & $\begin{array}{l}\text { Contractors- Internal } \\
\text { Certification } \\
\text { RL - Certification }\end{array}$ \\
\hline $\begin{array}{l}\text { PCB Annual } \\
\text { Document Log }\end{array}$ & $\begin{array}{l}\text { Information on TSCA-regulated PCB waste is } \\
\text { required for the document log including waste } \\
\text { weights and descriptions, container ID numbers, } \\
\text { manifest information for PCBs sent offsite for } \\
\text { disposal, and date of disposal }\end{array}$ & TSCA Regulations & $\begin{array}{l}\text { None } \\
\text { (Not sent to } \\
\text { regulators) }\end{array}$ \\
\hline $\begin{array}{l}\text { PCB Annual Status } \\
\text { Report on Storage of } \\
\text { PCBs }\end{array}$ & $\begin{array}{l}\text { Report requires container ID numbers, PCB waste } \\
\text { weights and descriptions, PCB out-of-service } \\
\text { dates, and programmatic information on current or } \\
\text { alternative PCB disposal technologies. Data on } \\
\text { TSCA-regulated PCB waste that contains } \\
\text { radioactive constituents and PCB waste that } \\
\text { contains both radioactive and RCRA constituents. }\end{array}$ & $\begin{array}{l}\text { Compliance Agreement } \\
\text { with EPA }\end{array}$ & None \\
\hline $\begin{array}{l}\text { RCRA Section } 3016 \\
\text { Biennial Report }\end{array}$ & $\begin{array}{l}\text { Data on environmental monitoring, hydrogeologic } \\
\text { site characterization, environmental } \\
\text { contamination, and response actions is required. } \\
\text { Also information on RCRA TSD Facilities that } \\
\text { managed hazardous waste on or after November } \\
19,1980 \text {, including programmatic data and } \\
\text { facility descriptions. }\end{array}$ & Regulations & None \\
\hline $\begin{array}{l}\text { Effluent Information } \\
\text { System-Onsite } \\
\text { Discharge } \\
\text { Information System }\end{array}$ & $\begin{array}{l}\text { DOE requires its sites to annually compile and } \\
\text { send radionuclide release data for both liquid and } \\
\text { airborne discharges, by April } 1 \text { or each year. }\end{array}$ & DOE Order & None \\
\hline $\begin{array}{l}\text { Environmental } \\
\text { Releases }\end{array}$ & $\begin{array}{l}\text { This report presents data for radioactive and } \\
\text { nonradioactive substances released into the } \\
\text { environment during each calendar year. } \\
\text { Information includes general descriptions of } \\
\text { facilities, summary of nonroutine releases and } \\
\text { spills. }\end{array}$ & Contract & None \\
\hline
\end{tabular}


HNF-1773 Rev. 2

\begin{tabular}{|c|c|c|c|}
\hline Report & Information needed & $\begin{array}{l}\text { Requirea by contract } \\
\text { or regulations }\end{array}$ & Certifications \\
\hline $\begin{array}{l}\text { Radionuclide Air } \\
\text { Emission Report }\end{array}$ & $\begin{array}{l}\text { This report includes information on radionuclides } \\
\text { emitted to the atmosphere from Hanford Site } \\
\text { facilities, an assessment of the offsite dose to any } \\
\text { member of the public, and descriptions of point } \\
\text { sources }\end{array}$ & Regulatory & $\begin{array}{l}\text { CHG - certifies } \\
\text { ORP - certifies }\end{array}$ \\
\hline $\begin{array}{l}\text { Nonradioactive Air } \\
\text { Emission Inventory } \\
\text { Information }\end{array}$ & $\begin{array}{l}\text { Annually transmit a report on nonradioactive air } \\
\text { emissions to Ecology containing information on } \\
\text { operations having the potential to emit } \\
\text { combustion products from fossil fuels. }\end{array}$ & Regulations & None \\
\hline $\begin{array}{l}\text { Document DOE/PL- } \\
96-50^{\mathrm{a}}\end{array}$ & $\begin{array}{l}\text { Report for the Mapping and Marking of } \\
\text { Dangerous Waste Underground Pipelines } \\
\text { submitted to Ecology to meet conditions II.U \& V } \\
\text { described above. Private contractors will need to } \\
\text { comply with the detailed methods identified }\end{array}$ & $\begin{array}{l}\text { Requirement in HF RCRA } \\
\text { Permit }\end{array}$ & None \\
\hline $\begin{array}{l}\text { Annual Hanford Site } \\
\text { Environmental } \\
\text { Permitting Status } \\
\text { Report }\end{array}$ & $\begin{array}{l}\text { A report this is prepared annually and contains a } \\
\text { summary of all environmental permits. This } \\
\text { document is referenced in RCRA Permit and is } \\
\text { included in the Facility Operating Record. }\end{array}$ & RCRA Permit Condition & None \\
\hline $\begin{array}{l}\text { Projections of } \\
\text { Anticipated Costs for } \\
\text { Closure and } \\
\text { Postclosure }\end{array}$ & $\begin{array}{l}\text { Annual information required for any TSD unit } \\
\text { that is in final status, undergoing closure, has been } \\
\text { closed, or is in postclosure care during the } \\
\text { preceding fiscal year. Detailed cost estimates for } \\
\text { closure or postclosure care, including any } \\
\text { monitoring or maintenance being performed or } \\
\text { anticipated. }\end{array}$ & RCRA Permit Requirement & $\begin{array}{l}\text { Prime Contractors - } \\
\text { Certification } \\
\text { RL-Certification }\end{array}$ \\
\hline
\end{tabular}

$\mathrm{CHG}=\mathrm{CH} 2 \mathrm{M}$ HILL Hanford Group, Inc.

DOE $=$ U.S. Department of Energy

Ecology $=$ Washington State Department of Ecology

EPA $=$ U.S. Environmental Protection Agency

EPCRA = Emergency Planning and Community Right-to-Know Act of $1986^{\mathrm{b}}$

$\mathrm{HQ}=$ U.S. Department of Energy Headquarters

LDR $=$ Land Disposal Restrictions

ORP $=$ U.S. Department of Energy, Office of River Protection

$\mathrm{PCB}=$ polychlorinated biphenyl

RCRA $=$ Resource Conservation and Recovery Act of $1976^{\circ}$

$\mathrm{RL}=$ U.S. Department of Energy, Richland Operations Office

TPA $=$ Tri-Party Agreement ${ }^{d}$

TSCA $=$ Toxic Substances Control Act of $1976^{\circ}$

$\mathrm{TSD}=$ treatment, storage and disposal.

${ }^{2}$ RL, 1996, Hanford Facility RCRA Permit Condition II.U.I Report: Mapping of Underground Piping, DOE/RL-96-50,

Rev. 0, U.S. Department of Energy, Richland Operations Office, Richland, Washington

${ }^{\mathrm{b}}$ Emergency Planning and Community Right-To-Know Act of 1986, as amended, 42 USC 1101 et seq.

${ }^{c}$ Resource Conservation and Recovery Act of 1976, as amended, 42 USC 6901 et seq.

${ }^{\mathrm{d}}$ Ecology, EPA, and DOE, 1996, Hanford Federal Facility Agreement and Consent Order, 2 vols. Washington State

Department of Ecology, U.S. Environmental Protection Agency, and U.S. Department of Energy, Olympia, Washington

${ }^{\mathrm{e}}$ Toxic Substances Control Act of 1976, as amended 15 USC 2601 et seq. 
HNF-1773 Rev. 2

\section{DISTRIBUTION}

\section{Onsite}

U.S. Department of Energy

Richland Operations Office

Reading Room

$\mathrm{H} 2-53$

1

Pacific Northwest National Laboratory

Hanford Technical Library

P8-55

2

Lockheed Martin Services, Inc.

Central Files

B1-07

Document Processing Center

A3-94

Distr.-1 
HNF-1773 Rev. 2

This page intentionally left blank.

Distr.-2 